\title{
Struktur Populasi Hirangan (Trachypithecus cristatus) di Desa Beringin Kencana Kabupaten Barito Kuala
}

\author{
Annisa Aliffira Syaumi ${ }^{1 *}$, Mahrudin $^{2}$, Riya Irianti ${ }^{3}$ \\ 1,2,3 Jurusan Pendidikan Biologi FKIP Universitas Lambung Mangkurat, Indonesia \\ ${ }^{*}$ Koresponden Penulis : annisaaliffira@gmail.com
}

\begin{abstract}
ABSTRAK
Beringin Kencana merupakan sebuah desa yang berada di Kabupaten Barito Kuala Provinsi Kalimantan Selatan dengan memiliki kawasan yang beragam. Daerah ini merupakan daerah yang belum terpublikasi luas, terutama keberagaman flora dan fauna yang ada, sehingga perlu diperkenalkan kepada publik secara luas. Tujuan penelitian ini adalah untuk mendeskripsikan strutur populasi Hirangan di Desa Beringin Kencana. Penelitian dilakukan dengan metode jelajah dengan teknik IPA Concentrat Count. Dimana hasil penelitian menunjukkan bahwa populasi Hirangan di Desa Beringin Kencana adalah, untuk jumlah individu dewasa sebanyak 2,61 individu/Ha muda sebanyak 1,07 individu/Ha dan anakan sebanyak 1,90 individu/Ha. Piramida pada struktur populasi hirangan di desa beringin kencana berbetuk pasu/kendi. Piramida berbetuk pasu/kedi menunjukan bahwa jumlah umur muda lebih sedikit dari jumlah umur dewasa.
\end{abstract}

Kata kunci: Struktur Populasi, Hirangan (Tracypithecus cristatus), Desa Beringin Kencana

\begin{abstract}
Beringin Kencana is a village located in Barito Kuala Regency, South Kalimantan Province with a diverse area. This area is an area that has not been widely publicized, especially the diversity of flora and fauna that exist, so it needs to be introduced to the public at large. The purpose of this study was to describe the structure of the Hirangan population in Beringin Kencana Village. The research was conducted using the exploratory method with the IPA Concentrat Count technique. Where the results of the study indicate that the population of Hirangan in Beringin Kencana Village is, for the number of adults as many as 2.61 individuals/Ha, young as many as 1.07 individuals/Ha and tillers as many as 1.90 individuals/Ha. Pyramid on the population structure of the hirangan in the Banyan Kendi village is in the form of an urn/kendi. Pyramid shaped caddy shows that the number of young people is less than the number of adults.
\end{abstract}

Keywords: Structur Population, Hirangan (Tracypithecus cristatus), Beringin Kencana Vilage

doi: $10.33474 /$ e-jbst.v7i2.481

Diterima tanggal 15 Desember 2021- Diterbitkan Tanggal 29 Januari 2022 http://creativecommons.org/licenses/by/4.0 


\section{Pendahuluan}

Populasi adalah sekelompok spesies dengan individu yang sama, tengah menempati tempat yang sama dan waktu serta pada wilayah tertetu [1]. Populasi ialah gabungan individu sejenis yang mendiami suatu wilayah dan memiliki karakteristik struktural tertentu yang tidak dalam satu cakupan secara tunggal [2]. Populasi didefinisikan sebagai sekumpulan organisme dengan kriteria yang berbeda dan banyak di daerah yang sama. Ketika ditemukan individu yang heteroseksual ditemukan bersama, tidak menutup kemungkinan ada persilangan secara bebas antar anggota individu atau persilangan dengan orang lain [3].

Kajian struktur populasi sangat penting dilakukan untuk menentukan bagaimana status atau keadaan suatu populasi dalam suatu habitat. Menurut Hardiansyah struktur populasi meliputi densitas dan pola distribusi, demografi tumbuhan, stadia dan umur, fekunditas, struktur umur dan struktur stadia. Biasanya populasi yang sedang berkembang cepat mengandung sebagian besar individu-individu muda.[4]

Hirangan merupakan nama lokal dari Lutung Kelabu di Kalimantan Selatan. Hirangan (Trachypihecus cristatus) memiliki ciri-ciri dengan warna (rambut hampir dominan hitam keperakan, kulit wajah hitam atau abu-abu), adanya perbedaan panjang tubuh jantan \& betina dewasa berkisar 470$550 \mathrm{~mm}$, panjang ekor 600-750 mm dan hirangan punya jambul di kepalanya.

Habitat utama hirangan adalah hutan hujan namun kadang-kadang juga ditemukan di daerah perkebunan karet, hutan primer dan daerah perbukitan hingga 600 mdpl. Jenis pakan hirangan adalah sengon tekik (Albizia sp.), ipik (Ficus superba), tutup (Mallotusfloribundus), pasang (Quercus sundaica) dan jambuan (Syzygium $\mathrm{sp}$ ) [5].

Hirangan merupakan salah satu hewan yang dilindungi. Berdasarkan hasil evaluasi Lembaga Konservasi Dunia International Union for Conservation of Nature an Natural Resources (IUCN). Spesies hirangan termasuk ke dalam status Appendix II atau yang artinya spesies tidak selalu terncam kepunahannya, namun tetap harus selalu di awasi untuk menghindari segala hal yang membahayakan kelangsungan hidupnya. Hal ini dikarenakan perburuan liar yang terus berlangsung sehinggan terancam keberadaannya [6].

Tujuan dari penelitian ini adalah mendeskripsikan struktur populasi Hirangan yang ada di Desa Beringin Kencana sehingga dapat dijadikan sebagai bahan pengamatan bagi pembelajaran dan penelitian yang selanjutnya. Karena Hirangan ini bermanfaat bagi suatu kawasan, yaitu sebagai penyeimbang ekosistem dan sebagai penyebar biji tanaman. Salah satu tempat hidup hirangan berada di Desa Beringin kencana Kabupaten Barito Kuala Provinsi Kalimantan Selatan. Dimana pada daerah ini terdapat kawasan mangrove, hutan rawa, persawahan, pemukiman dan perkebunan.

Daerah ini terletak di perbatasan wilayah Barito Kuala dan berbatasan dengan Kalimantan Tengah, merupakan daerah yang belum terpublikasi secara luas, terutama keberagaman flora dan fauna yang ada. Sehingga perlu diperkenalkan kepada publik secara luas. Desa beringin kencana dapat menjadi habitat berbagai macam jenis hewan, terutama hirangan karena daerah ini menyediakan sumber daya makanan dan tempat berkembangbiak yang cocok bagi kehidupan hewan tersebut.

\section{Material dan Metode}

\section{Bahan dan Alat}

Alat digunakan sebagai berikut: Kamera DSLR, anemometer, thermometer dan hygrometer

\section{Cara Kerja}

Penelitian dilakukan dengan mengobservasi secara langsung di Desa Beringin Kencana Kabupaten Barito Kuala dan menentukan objek penelitian yaitu Hirangan. Pengamatan dilakukan di 6 
e-Jurnal Ilmiah BIOSAINTROPIS (BIOSCIENCE-TROPIC)

Volume 7/ No.: 2 / Halaman 112 -118 / Januari Tahun 2022

ISSN : 2460-9455 (e) - 2338-2805(p)

titik menggunakan metode jelajah dengan teknik IPA Concentrat count untuk mengitung populasi serta menghitung jumlahnya. Pengamatan dilakukan selama 2 hari dari jam 07.00-18.00 WITA.

Membuat hasil analisis hirangan yang ditemukan dengan rumus:

$$
K=\text { ind } / H a
$$

Keterangan :

$\mathrm{K}=$ Kerapatan Pupulasi

Ind $=$ jumlah individu yang didapatkan

$\mathrm{Ha}=$ luas wilayah penelitian

Selanjutnya membuat gambaran piramida struktur populasi yang mengacu pada Odum (1993) serta melakukan perhitungan parameter lingkungan yaitu suhu udara, kecepatan angin dan kelembapan udara.

\section{Hasil dan Diskusi}

Berdasarkan hasil pengamatan di Desa Beringin Kencana ditemukan 6 kelompok hirangan pada 6 titik pengamatan, Hirangan ini di kelompokan berdasarkan umur yaitu Hirangan anakan, Hirangan Muda dan Hirangan dewasa..

Tabel 1. Titik Koordinat Pengambilan Sampel

\begin{tabular}{ccccc}
\hline Wilayah & Titik & GPS & $\begin{array}{c}\text { Luas wilayah } \\
\mathbf{2 0 \%}\end{array}$ & Dalam 1000 Ha \\
\hline I & $1 \& 2$ & $69,407 \mathrm{~m} 2$ & 13,88 & 1,39 \\
\hline II & $3 \& 4$ & $16,792 \mathrm{~m} 2$ & 3,358 & 0,33 \\
\hline III & 5 & $14,732 \mathrm{~m} 2$ & 2,946 & 0,29 \\
\hline IV & 6 & $321,277 \mathrm{~m} 2$ & 64,255 & 6,43 \\
\hline & Total & $422,145 \mathrm{~m} 2$ & 84,440 & $8,44 \mathrm{Ha}$ \\
\hline
\end{tabular}
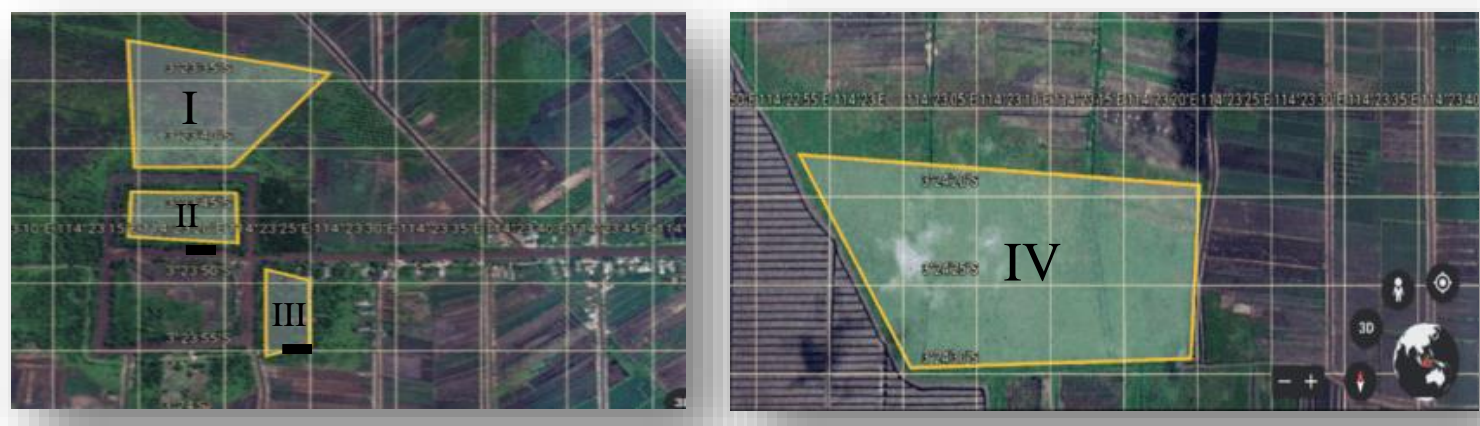

Gambar 1. Titik Koordinat pengambilan sampel [10]

Hirangan (Trachypithecus cristatus) di Desa Beringin Kencana Kabupaten Barito Kuala, mendiami habitat pada daerah kawasan hutan mangrove,hutan galam, kebun karet dan kebun sawit. 
e-Jurnal Ilmiah BIOSAINTROPIS (BIOSCIENCE-TROPIC)

Volume 7/ No.: 2 / Halaman 112 -118 / Januari Tahun 2022

ISSN : 2460-9455 (e) - 2338-2805(p)

Ketersediaan tempat yang beragam dan sumber makanan yang cukup melimpah, membuat keberadaan hirangan pada daerah penelitian cukup banyak.

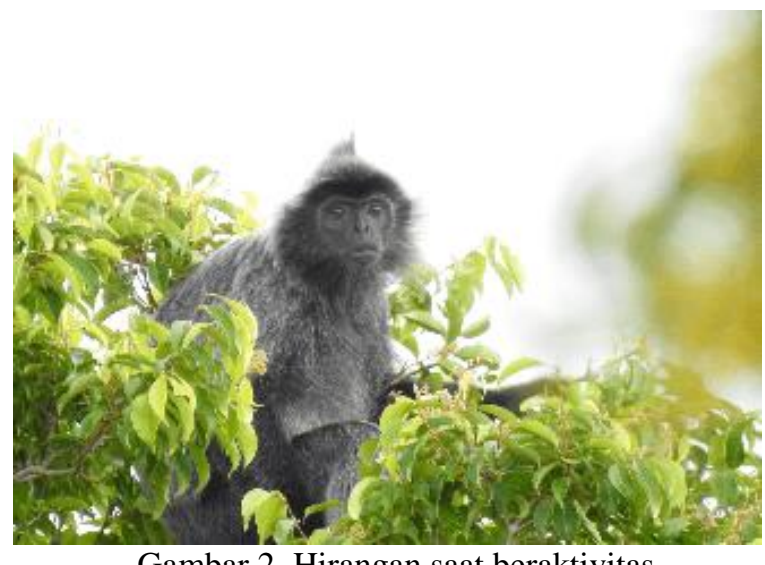

Gambar 2. Hirangan saat beraktivitas

Berdasarkan hasil pengamatan di Desa Beringin Kencana Kec. Tabunganen Kab. Barito Kuala dengan luas area 8,44 Ha, Pada tabel dibawah jumlah populasi hirangan yang paling banyak di dapatkan yaitu pada titik 1 dan titik 2 yaitu sebanyak 11 individu. Pada titik I jumlah Anakan Hirangan lebih banyak dari pada jumlah muda dan dewasa, namun pada titik II jumlah Hirangan dewasa lebih mendominasi dari pada Hirangan anakan dan Hirangan muda. Lebih jelasnya seperti yang terdapat pada tabel dibawah ini

Tabel 2. Struktur populasi hirangan yang ditemukan

\begin{tabular}{|c|c|c|c|c|c|c|}
\hline \multirow[t]{2}{*}{ Wilayah } & \multirow[t]{2}{*}{ Titik } & \multicolumn{3}{|c|}{ Struktur Populasi Berdas Umur } & \multirow[t]{2}{*}{$\sum$ ind } & \multirow[t]{2}{*}{ Keterangan } \\
\hline & & Anakan & Muda & Dewasa & & \\
\hline \multirow[t]{2}{*}{ I } & 1 & 5 & 2 & 4 & 11 & \\
\hline & 2 & 3 & 2 & 6 & 11 & \\
\hline \multirow[t]{2}{*}{ II } & 3 & 3 & 2 & 5 & 10 & \\
\hline & 4 & 2 & 1 & 2 & 5 & \\
\hline III & 5 & 1 & 1 & 3 & 5 & \\
\hline \multirow[t]{4}{*}{ IV } & 6 & 2 & 1 & 2 & 5 & \\
\hline & $\sum$ & 16 & 9 & 22 & 47 & \\
\hline & $\mathrm{K}$ ind/Ha & 1,90 & 1,07 & 2,61 & & \\
\hline & $\mathrm{K}$ ind/100 Ha & 190 & 107 & 261 & & Rendah \\
\hline
\end{tabular}

Berdasarkan data struktur populasi Hirangan pada Tabel 2, didapatkan hasil total yaitu jumlah hirangan dewasa lebih banyak ditemukan dibandingkan dengan jumlah hirangan anakan. Hirangan anakan ditemukan sebanyak 1,90 individu/Ha, Hirangan muda ditemukan sebanyak 1,07 individu/Ha, dan Hirangan dewasa ditemukan sebanyak 2,61 individu/Ha.Untuk mengetahui status kelangkaan 


\section{e-Jurnal Ilmiah BIOSAINTROPIS (BIOSCIENCE-TROPIC) Volume 7/ No.: 2 / Halaman 112 -118 / Januari Tahun 2022 ISSN : 2460-9455 (e) - 2338-2805(p)}

Hirangan pada wilayah penelitian maka data tersebut dikonversikan ke dalam jumlah total hirangan dewasa per $100 \mathrm{Ha}$ didapatkan hasil yaitu 261 individu/100Ha, sehingga didapatkan bahwa kerapatan hirangan dalam $10 \mathrm{Ha}$ pada satu kawasan pada daerah penelitian termasuk pada kategori "Rendah". Dalam buku Redlist Data Book of Endangered Species [6].

Berdasarkan jumlah populasi tersebut jika digambarkan dalam piramida struktur populasi maka akan terlihat gambaran jelasnya seperti berikut:

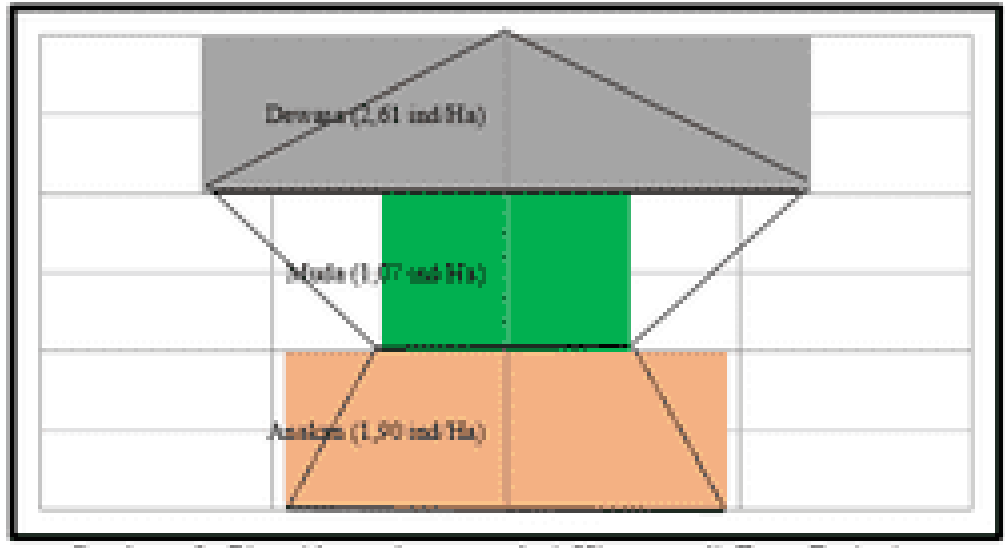

Gambar 3. Piramida struktur populasi hirangan

Gambar 3. menunjukan bahwa jumlah populasi yang lebih besar adalah kelompok dewasa dibandingkan dengan kelompok muda dan anakan. Bentuk struktur umum tersebut menggambarkan struktur populasi hirangan berbentuk pasu atau kendi. Berdasarkan gambar 2 diketahui bahwa struktur populasi hirangan di Desa Beringin Kencana digambarkan kedalam piramida berbentuk pasu/kendi. Hal ini ditunjukan oleh jumlah individu anakan lebih kecil dari jumlah individu dewasa. Akibat sedikitnya jumlah anakan dibandingkan dengan dewasa akan berimbas pada generasi mendatang. Penyebab dari hal tersebut adalah diakibatkan adanya perburuan liar, rusaknya habitat akibat pembukaan lahan seperti pembukaan lahan untuk pertanian dan perkebunan. Selain itu juga diakibatkan adanya ketersediaan sumber makanan yang terbatas sehingga mempengaruhi jumlah
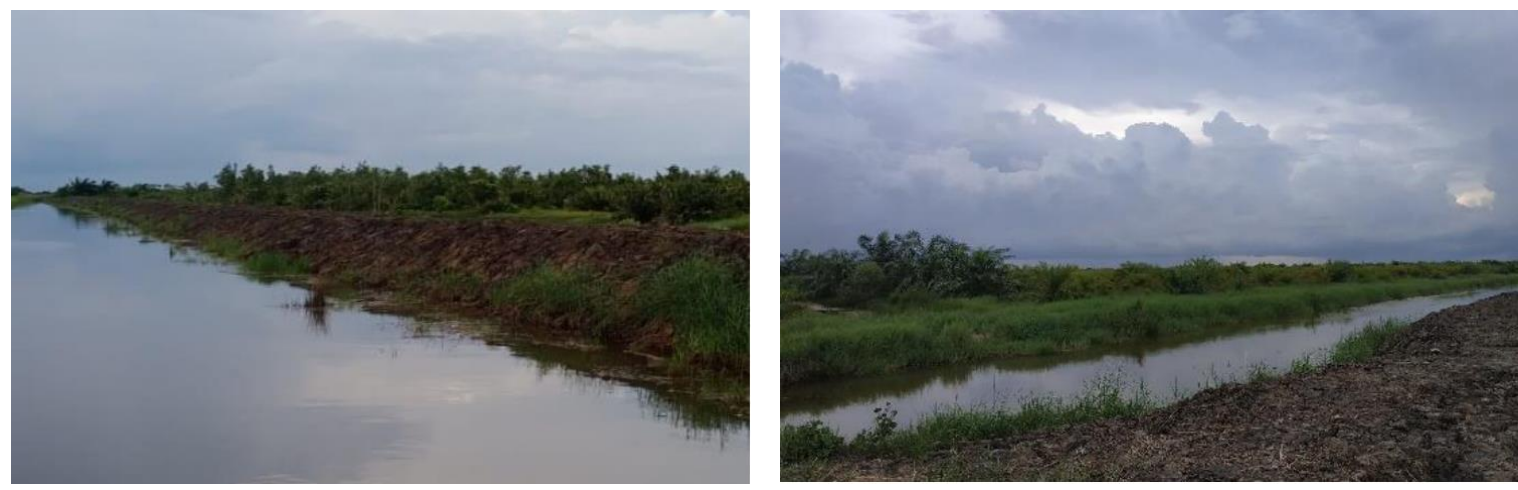

Gambar 4. Foto Pembukaan Lahan Perkebunan Baru

Menurut Odum [7], piramida berbentuk pasu/kendi menunjukkan jika jumlah kelompok umur muda lebih kecil dibandingkan jumlah kelompok umur tua, maka dapat diperkirakan keberadaan hirangan pada kawasan penelitian akan mengalami kelangkaan. Oleh karena itu perlu kesadaran dari masyarakat untuk senantiasa selalu menjaga lingkungan dan alam sekitar untuk menghindari kepunahan yang terjadi pada fauna dan flora pada masa mendatang.

Selain faktor habitat dan pakan, faktor abiotik juga berperan dalam keberlangsungan hidup hewan terutama Hirangan.populasi yang ditemukan. 
e-Jurnal Ilmiah BIOSAINTROPIS (BIOSCIENCE-TROPIC)

Volume 7/ No.: 2 / Halaman 112 -118 / Januari Tahun 2022

ISSN : 2460-9455 (e) - 2338-2805(p)

Tabel 3. Parameter Lingkungan

\begin{tabular}{cccc}
\hline No & Pengukuran & Satuan & Kisaran \\
\hline $\mathbf{1}$ & Suhu udara & ${ }^{\circ} \mathrm{C}$ & $28-31$ \\
$\mathbf{2}$ & Kecepatan angin & $\mathrm{m} / \mathrm{s}$ & $0,2-3,8$ \\
$\mathbf{3}$ & Kelembapan udara & $\%$ & $90-91$
\end{tabular}

Pada saat penelitian suhu udara pada lokasi penelitian berkisar antara $28-30^{\circ} \mathrm{C}$. Suhu udara berpengaruh pada ativitas harian Hirangan dimana suhu udara yang tinggi mengakibatkan Hirangan lebih banyak berdiam diri dan berlindung di bawah tajuk pohon yang rindang. Pada saat penelitian ditemukan hirangan berada dibawa pepohonan yang rimbun untuk beristirahat .

Selanjutnya Pada lokasi penelitian kelembapan udara berkisar antara 90-91\%, hal ini menunjukan bahwa pada lokasi penelitian sejuk karena kelembapan udaranya yang tinggi. Kegiatan istirahat pada primata termasuk Lutung (Hirangan) umumnya dipengaruhi oleh tingkat suhu dan kelembaban udara. Kelembapan sejalan dengan temperature udara yang mempunyai peranaan penting dalam mengatur aktivitas orgganisme dan dalam membatasi penyebarannya. Suhu dan kelembaban udara mempengaruhi perilaku satwa di alam. Pada saat suhu atau kelembaban tidak sesuai maka satwa akan merasakan stress. Gangguan ini akan menyebabkan satwa tidak nyaman pada habitatnya.

Kesesuaian suhu dan kelembaban merupakan hal utama yang harus diperhatikan untuk menjaga satwa tetap merasa nyaman dan beraktivitas secara alami. Kecepatan angin pada lokasi penelitian berkisar antara $0,2-3,8 \mathrm{~m} / \mathrm{s}$, hal ini menunjukan bahwa lokasi penelitian cukup sejuk. kecepatan angin dapat memberi pengaruh terhadap mortalitas hewan, hal ini dikarenakan angin yang kencang dapat menumbangkan pohon, sehingga hewan dapat mengalami kematian karena tertimpa benda yang ditumbangkan oleh angin. Akan tetapi angin juga tetap diperlukan oleh tumbuhan dalam hal ini tumbuhan pakan dalam rangka membantu proses penyebaran. Angin juga bisa sebagai pendingin badan hirangan saat cuaca sedang panas atau terik matahari, sama halnya dengan manusia [8]. Kecepatan angin di wilayah Kalimantan Selatan berkisar antara 0,3-0,5 m/s . Jadi pada kawasan penelitian angin tidak terlalu kencang dan masih banyak terdapat pohon yang hidup sebagai habitat alami hirangan.

Parameter lingkungan yang diukur selama pengamatan diduga tidak terlalu memberikan sedikit efek pada populasi hirangan di kawasan tersebut. Mirip dengan studi penelitian yang lain hanya kebanyakan membahas faktor biotik dari pada abiotiknya.

\section{Kesimpulan}

Struktur populasi Hirangan (Trachypithecus cristatus) di Desa Beringin Kencana yang diperoleh dengan menggunakan metode jelajah total berdasarkan IPA Concetrate count ditemukan kelompok Hirangan pada 6 titik pengamatan yang dilakukan. Hirangan anakan ditemukan sebanyak 1,90 individu/Ha, Hirangan muda ditemukan sebanyak 1,07 individu/Ha, dan Hirangan dewasa ditemukan sebanyak 2,61 individu/Ha. Hirangan dewasa lebih banyak ditemukan dibandingkan dengan jumlah hirangan anakan. Jika dilihat dalam bentuk piramida struktur populasi maka gambaran jelasnya adalah berbetuk berbentuk pasu/kendi. Piramida berbentuk pasu/kendi menunjukkan jika jumlah kelompok umur muda lebih kecil dibandingkan jumlah kelompok umur tua, maka dapat diperkirakan keberadaan hirangan pada kawasan penelitian akan mengalami kelangkaan. 
e-Jurnal Ilmiah BIOSAINTROPIS (BIOSCIENCE-TROPIC)

Volume 7/ No.: 2 / Halaman 112 -118 / Januari Tahun 2022

ISSN : 2460-9455 (e) - 2338-2805(p)

\section{Ucapan Terima Kasih}

Alhamdulillah penulis panjatan ke hadirat Allah SWT, karena atas rahmat dan hidayahNya, kepada orang tua yang selalu mendoakan \& mendukung. Penulis megucapkan Terima kasih pada dosen pembimbing satu dan dua yang terhormat atas ketersediannya membimbing, dan dosen penguji, sehingga dapat menyelesaikan penelitian ini, serta masukan dan saran yang telah diberikan, serta pihak yang membantu dalam penelitian maupun penyusunan artikel ini.

\section{Daftar Pustaka}

[1] Nadler, T. F Momberg, NX Dang and N Lormee. (2002). "Leaf Monkeys". Vietnam Primates Conservation Review-Part 2. www.fauna-flora.org. (Diakses on 22 April 2021).

[2] Brower, E., \& Zar, H. J. (1977). "Field And Laboratory Methods For General Ecology". Dubuque,Iowa: Nm.C.Brown Company Publisher

[3] Boughy, A. S. (1973). "Ecologyof Populations,Secondedition”. New York: Macmillan Publishing Co.

[4] Hardiansyah. 2010. Pengantar Ekologi Tumbuhan. Banjarmasin: Fakultas Keguruan dan Ilmu Pendidikan UNLAM

[5] Utami, W. F. (2016). "Pengembangan Media Booklet Teknik Kaitan Untuk Peserta Didik Kelas X Smkn 1 Saptosari Gunung Kidul”. Skripsi, Universitas Negeri Yogyakarta. Diakses Melalui Www.Eprints.Uny.Ac.Id/55023 Pada Tanggal 2 Februari 2021

[6] Sukarsono. (2009). Pengantar Ekologi Hewan; Konsep, Perilaku, Psikologi dan Komunikasi. Malang: UMM Press.

[7] Odum, E. P. (1993). “Dasar- Dasar Ekologi”. Yogyakarta: Gadjah Mada University Prees.

[8] Supriana, J., \& Wahyono, E. H. (2000). "Panduan Lapngan Primata Indonesia”. Jakarta: Yayasan Pustaka Obor Indonesia.

[9] IUCN. (2008). “Trachypithecus Auratus”. Www.Iucnredlist.Org/Species/22034/9348260 (Diakses Pada 10 Maret 2021)

[10] https://www.google.co.id/maps/ (Diakses Pada 10 Maret 2021) 